\title{
Evaluation of 16 Barley Genotypes under Calcareous Soil Conditions in Egypt
}

\author{
Mohamed Naguib El-Banna \\ Plant Production Dep., Faculty of Agriculture (Saba Basha) \\ Alexandria University, Alexandria, Egypt \\ Mohamed Ahmed Abd El-Gawad Nassar \\ Plant Production Dep., Faculty of Agriculture (Saba Basha) \\ Alexandria University, Alexandria, Egypt \\ Maher Noaman Mohamed (Corresponding author) \\ Barley Res. Dep., Field Crops Res. Inst., Agricultural Res. Center \\ P.O. Box 12619, Giza, Egypt
}

Tel: 2012-170-5770 E-mail: mahernoaman@yahoo.com

Mohamed Abd El-Azeem Boseely

Nubartia Experimental Res. Stn., Barley Res. Dep., Field Crops Res. Inst.

Agricultural Res. Center, P.O. Box 12619, Giza, Egypt

Tel: 2010-642-6073 E-mail: mbussily@yahoo.com

This research was financially supported by Field Crops Research Institute, Agricultural Research Center, Egypt, in collaboration with Faculty of Agriculture (Saba Basha), Alexandria University, Alexandria, Egypt.

\begin{abstract}
A field experiment was carried out in the Experimental Research Station at Nubaria, ARC representing newly reclaimed areas during two successive seasons of 2005/06 and 2006/07 to evaluate 16 barley (Hordeum vulgare L.) genotypes grown under water stress and calcareous soil conditions. The evaluation included yield and its components, growth attributes, earliness and kernel protein content. A randomized complete block design was used with three replications. Only two irrigations, i.e. at sowing and heading were applied to expose plants to water stress. Results showed that there are significant differences among the 16 barley genotypes for most of the characteristics. Four barley genotypes; Malouk//Aths/Linee686,Alanda-02/4/Arizona5908, Alanda/3/CI08887/CI05761//Lignee640, and Alanda/ Harma//Alanda01out yielded the check cultivars in grain and biological yield with some other advantages such as earliness, harvest index, leaf area index, and higher protein content. It is suggested that those genotypes could have more genetic stability studies to be grown in such calcareous soils.
\end{abstract}

Kewwords: Hordeum vulgare, Leaf area index, Harvest index, Evaluation

\section{Introduction}

Barley (Hordeum vulgare L.) is the main crop grown in a large scale in the North Coastal Region of Egypt and also in the newly reclaimed lands with saline soils and shortage of fresh water. It is mainly used for animal forages and recently it is used as human food because of its nutritional and healthy values in most countries using hull-less barley. Barley area in the Nile Valley of Egypt has been gradually declined, especially at locations where soil and irrigation is feasible and can be grown with other strategic crops such as wheat. On the other hand, barley production area increased in the new reclaimed lands under different irrigation systems. The total harvested area was 57,000 ha in the eighties, while it became 135,000 ha in 2008/09. Barley yields have tended to increase gradually over the past three decades from $2.92 \mathrm{t} \mathrm{ha}^{-1}$ in the eighties to $3.63 \mathrm{t} \mathrm{ha}^{-1}$ in $2008 / 09$. 
Under rainfed conditions, barley productivity increased from $0.44 \mathrm{t} \mathrm{ha}^{-1}$ during the period $1986-1991$ to $1.9 \mathrm{t} \mathrm{ha}^{-1}$ in 2008/09. In Egypt, rainfed barley productivity is considered high compared to other rainfed areas in the world, which exceeds $200 \mathrm{~mm}$, while the rainfall in Egypt is less than $130 \mathrm{~mm}$ on the average. Barley grains are used in blends with other feed materials for most farm animals. Barley malt is used in making malted milk, barley foods, and in brewing industry. Attempts to improve nutritional value of the barley grains are being made by increasing protein content and by improving amino acid balance in the grain protein through higher lysine content.

Constraints facing barley production in Egypt are numerous, some of which are; environmental problems such as drought, salinity, poor soil fertility, and high temperature, besides some biotic stresses particularly diseases such as net blotch, powdery mildew, leaf rust, viral diseases such as Barley Yellow Dwarf Virus (BYDV) and Barley Stripe Mosaic Virus (BSMV) and insects mainly aphids. Other problems are the lack of suitable cultivars, especially for calcareous soils and newly reclaimed lands. Another problem is the low inputs by farmers, especially fertilizers because of unavailability in the market and/or the unavailability of cash. Continuous barley is a common practice, especially in the rainfed areas; some farmers have already adopted barley-lentil or barley-vetch rotations. Marketing difficulty is another problem facing barley production to a lesser extents. In Egypt, barley is the best choice in the risky conditions such as in poor soils and in newly reclaimed areas, which suffer from water shortage and water quality.

Nubaria Research Station represents the newly reclaimed and calcareous soils of this region, and has contributed deeply in the program of barley breeding for long time. This led us to suggest the present study to test 13 promising barley genotypes in addition to three long-time checks high-yielding cultivars which are also early-maturing and tolerant to barley diseases and barley pests and possessing high kernel protein content.

\section{Materials and methods}

The present investigation was carried out in the Experimental Research Station of Nubaria during the two successive seasons of 2005/2006 and 2006/2007. The station is located at $47 \mathrm{Km}$ South West of Alexandria city $\left(30.54^{0} \mathrm{~N}, 29.52^{0} \mathrm{E}\right)$ representing the newly reclaimed calcareous soils, which could be successfully cultivated by barley. The study was suggested to evaluate 16 barley (Hordeum vulgare L.) cultivars and genotypes grown under water stress condition at the calcareous soil of that region. The evaluation included yield and its components, growth attributes, earliness and grain protein content. A randomized complete block design was used with three replications. Soil samples were collected to determine soil type in which the experiments were performed (Table 1). Plot size (experimental unit) was $10.5 \mathrm{~m}^{2}$ (15 rows x $0.2 \mathrm{~m}$ x $3.5 \mathrm{~m}$ ). Seeding rate was 50 $\mathrm{Kg} \mathrm{acre}^{-1}$. Only two irrigations, i.e., at sowing and heading were applied. This regime aimed to expose plants to water stress. Seeds of the cultivated cultivars were obtained from the certified seed stock of the Ministry of Agriculture and Land Reclamation, while the seeds of the other genotypes were obtained from Barley Research Department, Field Crops Research Institute, Agricultural Research Center, Egypt. Sowing dates were $28^{\text {th }}$ and $29^{\text {th }}$ of November in the two successive seasons, respectively. The soil was prepared in both seasons as usually done in commercial production. Phosphorous fertilizer was applied during seedbed preparation at the rate of 60 $\mathrm{Kg} \mathrm{P}_{2} \mathrm{O}_{5}$ acre $^{-1}$ in the form of super phosphate $\left(15.5 \% \mathrm{P}_{2} \mathrm{O}_{5}\right)$. Potassium fertilizer was applied at $24 \mathrm{Kg} \mathrm{K} \mathrm{K}_{2} \mathrm{O}$ acre $^{-1}$ in the form of potassium sulphate $\left(48 \% \mathrm{~K}_{2} \mathrm{O}\right)$ at two equal doses. The first dose was applied during seedbed preparation, while the second was applied after 30 days from sowing. Nitrogen fertilizer was applied at

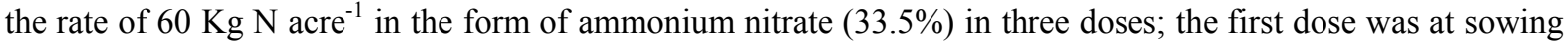
and the other two doses were applied at 21 and 45 days after sowing. All other agronomic (cultural) practices were followed during the growing seasons as usually recommended in the surrounding commercial barley production farms.

\subsection{Studied Characteristics}

The studied traits were divided into three categories, vegetative growth and earliness traits, yield and its components and grain protein content. These are the traits that are most likely affected by drought stress and calcareous soil conditions.

\subsection{Vegetative growth and earliness}

Days to Heading (DH): The number of days from germination (sowing date) to the date of the appearance of $50 \%$ of spikes was recorded / each plot (when $1 / 3$ of the spike exerted).

Plant height (cm): height of 10 random plants /plot measured as a distances from the bases of the culms to the tips of spikes (excluding awns). Data collected was averaged to be / plant.

Leaf Area Index: The total area of leaves / plant was determined after complete heading in each plot. The samples obtained then the leaves separated and fed in LI-COR (Model Li-3000A) device. 


\subsection{Yield and Yield Components}

Ten individual plants were chosen at harvest time as random from the middle of each plot to estimate:

Number of grains spike ${ }^{-1}$ : was obtained as number of grains of ten random spikes from each plot at harvest.

Spike weight (g): was expressed as average of ten spikes weight from each plot.

1000-kernel weight (g): was estimated as the weight of 1000 cleaned kernels in gram for each plot.

\section{Number of spikes $\mathbf{m}^{-2}$ :}

The number of spikes was taken from $1 / 4 \mathrm{~m}^{2}$, randomly inside each plot, then it was transformed into spikes /square meter.

Biological yield: the total biomass of the harvested plants $\left(\operatorname{Kg~plot}^{-1}\right)$, then it was transformed into $t$ acre ${ }^{-1}$

Straw yield (t $\mathbf{a c r e}^{-\mathbf{1}}$ ): After threshing, the yield of straw was calculated from (biological yield- grain yield) for each plot in $\mathrm{Kg}$, and then it was transformed into $\mathrm{t} \mathbf{a c r e}^{-1}$.

Harvest index: As usual, harvest index (H.I.) calculation in this investigation was as follows:

$$
\begin{aligned}
& \text { Grain yield (Kg acre } \left.{ }^{-1}\right) \\
& \text { H.I. = [ ------------------------- }] \text { x } 100 \\
& \text { Biological yield (Kg acre }{ }^{-1} \text { ) }
\end{aligned}
$$

Grain yield ( $\left.\mathbf{t ~ a c r e}^{-1}\right)$ : was obtained as the weight of clean grains of the plot after threshing, and then it was transformed into $\mathrm{t}$ acre $^{-1}$.

\subsection{Grain Protein Percent}

Total nitrogen was measured from samples taken from each experimental unit grain yields using the method adopted by Kjeldahl, as described by Egan et al. (1981). Protein percent was calculated as $\mathrm{N}_{2} \times 6.24$ (constant converter factor)

\subsection{Statistical analysis}

Data collected from the two seasons were statistically analyzed as a Randomized Complete Block Design (RCBD) using analysis of variance (ANOVA) for each season and over all the two seasons as a combined analysis. The means of genotypes and cultivars included in this trial compared using fisher test run by Least Significant Difference (L.S.D.) at $(P \leq 0.05)$ according to Steel and Torri (1982). All Statistical analyses were performed using the Statistical Analysis System (SAS, Ver. 6.1).

\section{Results and Analysis}

\subsection{Vegetative Growth and Earliness}

Regarding vegetative growth and yield components, El-Hindi et al (1998) in Egypt found that Giza 124 barley cultivar surpassed other barley cultivars in the plant height, number of spikes $\mathrm{m}^{-2}$, weight of grains spike ${ }^{-1}$, grain weight and grain yield per acre. Ghasemi (2001) studied multiple regression on nine (five 6-rowed and four 2-rowed) barley cultivars to identify the most effective characters and the contribution of these characters to grain yield. The multiple regression method revealed 12 characters contributing a total of $81.8 \%$ of grain yield variance. Harvest index and 1000-grain weight together shared contributed $65.1 \%$ of grain yield variance, with harvest index being the most important. The 12 characters together contributed $93.1 \%$ of the variance in the 1000-grain weight. Grain yield and flag leaf area, which had a close correlation with the 1000-grain weight, contributed $85.5 \%$ of the variance in the 1000-grain weight. The most important yield component was the 1000 -grain weight followed by harvest index.

\subsubsection{Days to Heading $(\mathrm{DH})$}

Data of the appearance of $50 \%$ of spikes presented in Table 3 show significant differences for this characteristic among barley genotype during the two seasons. Results in Table 15 show the means of DH of the 16 barley genotypes under study for the two seasons. The results showed that genotype no. 13 was the earliest in the first and second season (72.7 and 78.3 days), respectively. In addition, this genotype was the earlier across the two seasons having an average of 75.5 days. On the other hand, the latest genotypes was no.12 (96 days) in the first season, while genotype no. 4 and Giza 123 were the latest ones in the second season having (91 days) for each. In addition, genotypes no. 12 and 4 headed later over the two seasons ( 92.3 and 91.8 days), respectively. Those results are in agreement with those from Li, C.D. et al. (1991), El-Sayed et al. (1995), Asaad et al. (1998), and Afifi (1999). Data in Table 4 show clearly that there were no significant differences between the two seasons (S) 
for days to heading as well as seasons $\mathrm{x}$ genotypes $(\mathrm{SxG})$ interaction. These results were similar to those obtained by Jackson et al. (1994), Kosowska (1995), Oscarsson et al. (1998) and Afiah et al. (1999).

\subsubsection{Plant Height}

Plant height of the 16 barley genotypes showed significant differences among the genotypes under study. Data in Table 3 show high significant differences in the first season as well as over the two seasons. Table 15 shows the mean of plant height of the 16 studied genotypes for the two growing seasons and its average. Means of this trait clearly indicated that the check barley cultivar no. 3 (Giza 2000) was the tallest in each individual season and overall the two seasons recording $115.7,113.3$ and $114.5 \mathrm{~cm}$, respectively. On the other hand, the shortest genotypes were recorded by genotypes no. 11 and 8 in the first season $(86.0$ and $86.7 \mathrm{~cm})$, respectively, while the shortest one was genotype no. 9 in the second season $(86.7 \mathrm{~cm})$. However, genotype no. 11 was the shortest one overall the two seasons with an average of $90.5 \mathrm{~cm}$. The significant differences in plant height among barley genotypes might be attributed to the differences in their genetically constitution. These results are in agreement with those of Singh (1989), Li, C.D. et al. (1991), El-Hindi et al. (1998), Assad et al. (1998), Afifi (1999), and Afiah and Moselhy (2001). Significant interaction (GxS) between the two seasons (S) and Genotypes (G) for plant height was detected (Table 4). These results are in harmony with those of Jackson et al. (1994), Oscarsson et al. (1998), Afiah et al. (1999) and Afiah and Moselhey (2001).

\subsubsection{Leaf Area Index (LAI)}

Concerning leaf area index (LAI) and soil-plant analysis development (SPAD) of spring barley varieties, Jaskiewicz (2008) found that barley cultivars requiring low plant densities grown under increasing plant-to-plant distance recorded lower LAI and higher SPAD value compared to cultivars which required high plant densities. Also Sammis et al. (1986) measured leaf area index (LAI) of spring barley (Hordeum vulgare L.), to predict (LAI) under soil moisture stress and non-soil-moisture-stress conditions, reported that LAI was linearly related to cumulative evapotranspiration up to maximum LAI. Barley cultivars Cr.366, Giza 124 and Giza 123 were recognized with their higher values of water use efficiency.

In the present study, leaf area index of each genotype was estimated and data were analyzed and tabulated in Tables 5\&6. The data showed high significant differences among genotypes in LAI in the two seasons. Data in Table 15 indicate that the highest indices of leaf area were obtained from genotype no. 13 over the two seasons (3.2) as an average. In addition, it gave the highest LAI in the second season (3.1). Cultivar no.2 gave the second highest LAI over the two seasons (3.2). It also had the highest index in the first season (3.6). On the other hand, the lowest LAI was found with genotype no. 16 (2.2) in the first season and over the two seasons (2.21). Differences among the 16 barley genotypes in LAI was observed and was similar to the findings of Spunarova and Zenisceva (1985), Gontia and Khare (1992) and Hradecka (1994). The previous results explain the significant seasonal (S) effect shown in (Table 6) reflecting a lower average value of LAI in the second season (2.4) compared with the first season, which averaged (2.8) (Table 15). Table 6 also shows the highly significant effect of genotype $\mathrm{x}$ season $(\mathrm{G} \times \mathrm{S})$, which also explains how the LAI did not follow the same trend in both seasons due to the significant interaction and significant effect of environment on this characteristic. In this regard, Jamieson et al. (1994) revealed that drought stress reduced biomass yield through the effects on radiation interception by reducing LAI and radiation use efficiency. The relative influences depended on the timing of stress (Mansour, 1992).

\subsection{Yield and Yield Components}

\subsubsection{Number of Grains Spike ${ }^{-1}$}

Data of number of grains spike ${ }^{-1}$ (Table 6) show significant differences among the barley genotypes and their performance over the two seasons as well as in the second season. Table 16 elucidates that the average value of number of grains spike ${ }^{-1}$ was not significantly affected by genotypes in the first season, although there was some obvious trends. Genotype no. 16 gave an average of 63 grains spike $^{-1}$ followed by genotypes no. 4,15 and 11, with values of 62.2, 61.6 and 61.2, respectively. However, significant differences among barley genotypes were shown in the second season where genotype no. 12 gave the highest number of grains spike ${ }^{-1}(60.5)$ followed by genotype no. 15 (59.1). With regard to the average of the two seasons, data in Table 16 revealed that genotype no.15 produced the highest no. of grains spike ${ }^{-1}(60.4)$, followed by genotype no. 12 (59.5). On the other hand, the lowest no. of grains per spike was obtained by genotype no. 10 in the first season (47.5), while the commercial cultivar no. 3 and genotype no. 6 gave the lowest ones in the second season (37.4 and 42.4 grains spike $^{-1}$ ), respectively. Generally, the lowest genotypes over the two seasons with regard to number of grains spike $^{-1}$ were genotypes no. 6 (48.5) and cultivar no. 3 which gave only (48.7) grains spike ${ }^{-1}$. These results were in agreement with those obtained by Singh (1989), Hradecka (1994), and Afifi (1999). 
The combined analysis (Table 6) showed significant effect of the interaction between seasons (S) and environment (GxS) for the number of grains spike ${ }^{-1}$ in the second season with an average of about (49.6 grains spike $\left.^{-1}\right)$ in the second season compared with that obtained from the first season (57 grains spike ${ }^{-1}$ ) (Table 16).

\subsubsection{Spike Weight (g)}

Data on spike weight presented in (Tables 7\&8) show remarkable differences among barley genotypes either in single or in combined analysis of variance. Means of spike weights presented in Table 16 indicate that the heaviest spikes were shown by cultivar no. $3(3.9 \mathrm{~g})$ in the first season followed by $3.8 \mathrm{~g}$ for genotype no. 9 in the second season. However, genotypes no. 12, 15 and 13 recorded the highest values (3.7, 3.5 and $3.4 \mathrm{~g})$, respectively. As an average of the two seasons, genotype no.12 was the heaviest in spike weight $(3.7 \mathrm{~g})$ followed by genotype no. $13(3.5 \mathrm{~g})$. On the other hand, the lightest spikes were obtained form cultivar no.2 $(2.5 \mathrm{~g})$ in the first season followed by genotype no. $5(2.6 \mathrm{~g})$, while in the second season the lowest genotypes in this characteristic were no. 11 and 14 having $2.4 \mathrm{~g}$ for each, respectively, whereas over the two seasons, the lightest spikes were recorded by genotypes no. 11 and 14 having an average weight of $2.6 \mathrm{~g}$ for each. In this respect, these results agreed with those obtained by Weston et al. (1993), El-Hindi et al. (1998), and Afifi (1999). It was revealed that there was significant seasonal effect (S), which was evidenced by the high values of spike weights in the first season, with an average of $3.2 \mathrm{~g}$ compared with $3 \mathrm{~g}$ for the second season (Table 16).

\subsubsection{0-kernel Weight}

Data in Tables $7 \& 8$ show that there were high significant differences among genotypes in both growing seasons and over the two seasons for 1000-kernel weight. It was clear that cultivar no. 3 gave the heaviest 1000-kernel weight either in single or in combined analysis with about 52.3 and $61.5 \mathrm{~g}$ in the first and second seasons, respectively followed by genotype no. 9 , which gave $44.1 \mathrm{~g}$ in the first season and $60.0 \mathrm{~g}$ in the second season with an average of $52.0 \mathrm{~g}$ over the two seasons. Concerning the combined analysis, the lightest weights were observed by genotypes no. 10 and 12 , which gave 39.6 and $42.0 \mathrm{~g}$, respectively over the two seasons. The significant differences in 1000-kernels of barley should be attributed to the differences in grain filling period and dry matter accumulation in grains. These results are in agreement with those reported by Weston et al. (1993), Hradecka (1994), El-Sayed et al. (1995), El-Hindi el al. (1998), and Afifi (1999). It was clearly observed that the average weights of barley 1000-kernel were generally lighter in the first season compared to the second season (40.8 and $50.4 \mathrm{~g}$ ), respectively (Table 17). This variation might have been affected by the seasonal conditions which was significantly different in favor of the second season (Table 8). The significant differences between seasons and the GxS inter action was similar to results reported by Oscarsson et al. (1998).

\subsubsection{Number of Spikes $\mathrm{m}^{-2}$}

Data in Table 9 show that the variation among genotypes for the number of spikes per square meter characteristic was significant only in the first season and also when two seasons were analyzed together in the combined analysis (Table 10). The means of the genotypes given in Table 16 show that both genotypes no.11 and 15 gave the highest number of spikes $\mathrm{m}^{-2}$ in the first season (366 spikes for each), followed by cultivar no. 1 $\left(358\right.$ spikes $\mathrm{m}^{-2}$ ). In the second season, there was different trend, with 253 spikes for genotype no. 14 followed by 252 spikes for both genotypes no. 7 and no. 10. The average of the two seasons restricted the superiority towards cultivar no.1 (299 spikes $\left.\mathrm{m}^{-2}\right)$ in addition to genotypes no. 14, 7, 10 and 15, which gave 298, 294, 294 and 289 spikes $\mathrm{m}^{-2}$, respectively. On the other hand, the lowest number of spikes $\mathrm{m}^{-2}$ was obtained from genotypes no. 13 and 8 with 272 and 255 spikes $\mathrm{m}^{-2}$, respectively. The differences among genotypes' ability to produce a suitable number of tillers or tillers containing spikes might be attributed to its genetical constitutions, which is supported by the results reported by Singh (1989), Hradecka (1994), and El-Hindi et al. (1998). The combined analysis revealed that the first season significantly out yielded the second season in this characteristic, whereas GxS interaction was not significant (Tables 10\&16), which show that the average number of spikes $\mathrm{m}^{-2}$ was 325 in the first season compared to 226 in the second season.

\subsubsection{Biological Yield}

The analyses of variance for the biological yield (biomass) in $\mathrm{t}_{\text {acre }}{ }^{-1}$ for the two successive seasons are shown in Tables $9 \& 10$. The differences among genotypes were highly significant over the two seasons as well as in the first season. Genotype no.13 gave the highest biological yield in both seasons ( 8.2 and $6.2 \mathrm{t}$ acre $\left.\mathrm{e}^{-1}\right)$, respectively, with an average of $7.2 \mathrm{t} \mathrm{acre}^{-1}$ over the two seasons (Table 17). Moreover, genotype no. 4 was ranked second with about 7.96 and $4.88 \mathrm{t} \mathrm{acre}^{-1}$ in the two successive seasons, respectively having an average of $6.42 \mathrm{t} \mathrm{acre}^{-1}$. These results are similar to those obtained by Asaad et al. (1998) and Noaman et al. (1997). Data in Table 10 show that the two seasons and the (GxS) interaction were significantly different concerning this trait under Nubaria conditions. Generally, the first season was more suitable to reach a good biological yield with about 6.3 
and $4.1 \mathrm{t}$ acre $\mathrm{e}^{-1}$ in the two successive seasons, respectively (Table 17). The higher biological yield produced in the favorable conditions of the first season was supported by the results obtained by Jamieson et al (1994), Oscarsson et al. (1998) and Oboda et al. (2000).

\subsubsection{Straw Yield}

Straw yield values of barley genotypes are shown in Table 18. It is obvious from this table that differences among barley genotypes were highly significant over the two seasons (Tables 11\&12). Results showed that the behavior of the genotypes concerning this trait was parallel with those results obtained from the biological yield. This observation agreed with that recorded by Noaman et al. (1997), Assad et al. (1998), and Afifi (1999). It seems clearly that genotype no. 13 gave the highest significant weight of straw yield, recording 6.0 and $4.8 \mathrm{t}$ $\mathrm{acre}^{-1}$ for the two successive seasons, respectively with an average of $5.4 \mathrm{t} \mathrm{acre}{ }^{-1}$. However genotype no. 4 became second with about 5.7 and 3.7 for the two successive seasons, respectively with an average of $4.7 \mathrm{t}$ acre ${ }^{-1}$. The seasonal effect was significant for this trait following similar trend as was shown in the previous trait (biological yield). Generally, the first season gave the highest straw yields compared to the second season. The two successive seasons gave, on the average, 4.5 and $3.1 \mathrm{t} \mathrm{acre}^{-1}$, respectively (Table 18). The difference between seasons concerning straw yield was also affected by the favorable conditions present in the first season.

\subsubsection{Harvest Index (HI)}

Harvest Index values as a relation between grain yield and biological yield are presented in Table 18. Results showed that the differences among the barley genotypes under this study were highly significant when the data of the two seasons were combined and analyzed together in a combined analysis (Tables 11\&12). Means of harvest indices shown in Table 18 indicate that genotype no.10 had the highest (HI) in the first season (33.0\%), where it ranked second in the second season $(27.3 \%)$ as well as over the two seasons $(30.1 \%)$. However, genotype no. 15 gave the highest (HI) in the second season (36.1\%) as well as over the two seasons (31.7\%), while cultivar no.1 ranked second in the first season (32.4\%). On the other hand, the lowest harvest index was recorded by genotype no. 2, which is a check cultivar (Giza 126) - over the two seasons (23.8\%), and also in the second season (18.8\%). The variation among genotypes depends on the ability of genotype to transfer the dry matter accumulation towards grains. The results presented here were in agreement with those of Gouis (1992), Ellen (1993), and Assad et al. (1998). Concerning the seasonal effect, the data in Table 18 show that there were highly significant differences between the two seasons as well as in the (GxS) interaction. The harvest indices tended to be higher in the first season than in the second one with values of $29.4 \%$ and $24.5 \%$ in the first and second seasons, respectively (Table 12), which indicates that there was either higher grain yield or lower straw yield or both directions in the first season.

\subsubsection{Grain Yield}

Regarding grain yield and its response to drought stress, the Egyptian barley cultivar, Giza 125 out yielded the long-time check cultivar; Giza 123 in grain yield by about $25 \%$ with an average grain yield of $1110 \mathrm{Kg} \mathrm{ha}^{-1}$ under rainfed conditions of $<150 \mathrm{~mm}$ (Noaman et al., 1995 a). They also reported that the new drought-tolerant cultivar; Giza 126 has wider adaptability than Giza 125 cultivar under different levels of drought stress in rainfed areas, and more stable in performance and has greater tolerance to high stress environment compared with Giza 125 cultivar (Noaman et al. (1995 b). Noaman et al. (1997) found that the new drought-tolerant cultivar Giza 126 proved to be superior for grain yield, biological yield and straw yield compared to the other genotypes in their study, and exhibited wide adaptability across different environments under rainfed conditions. In general, high grain yielding genotypes gave high biomass and straw yields.

In the present study, significant differences for grain yield among barley genotypes were detected in and over the two seasons (Table 17) and (Tables 13\&14). Results showed that in the first season, the superiority was achieved by genotype no. 11 , which gave $2.26 \mathrm{tacre}^{-1}$ followed by no. $4,9,13,12$ and 7 , which respectively had 2.22 , $2.21,2.19,2.17$ and $2.13 \mathrm{t}_{\text {acre }}{ }^{-1}$ with significant increase over the three national checks. Moreover, results of the second season revealed that genotype no. 13, which was ranked fourth in the first season exceeded all other genotypes with an average grain yield of $1.36 \mathrm{t}_{\text {acre }}{ }^{-1}$, while genotype no. 11, which occupied the first ranking in the first season, became third with an average grain yield of $1.32 \mathrm{t}$ acre ${ }^{-1}$, followed by no. 4 and no. 12 (second and fifth in the first season) with an average of 1.19 and $1.18 \mathrm{t} \mathrm{acre}^{-1}$, respectively. It was concluded that genotypes no. 11, 13, 4, and 12, appeared in both seasons in the top four barley genotypes in regards to grain yield which was confirmed by the combined analysis over the two seasons. It was clear that genotype no. 11 had the highest grain yield over the two seasons $\left(1.79 \mathrm{t} \mathrm{acre}^{-1}\right)$ followed by genotype no. $13\left(1.78 \mathrm{t}\right.$ acre $\left.\mathrm{e}^{-1}\right)$, while genotype no's. 4 and 12 were ranked $3^{\text {rd }}$ and $4^{\text {th }}$ with average grain yields of 1.70 and $1.67 \mathrm{t} \mathrm{acre}^{-1}$, respectively (Table 17). On the other hand, the check barley cultivars (no's. 1, 2 and 3) exhibited lower yields compared to 
those above-mentioned four barley genotypes significantly in both seasons. Moreover, three barley genotypes, i.e., no's. 5, 6 and 16 either in each season individually or across the two seasons out yielded those three checks. Genotype no.11 which occupied the first ranking in grain yield had the shortest plants which agree with those results reported by Dwyer et al. (2001). The second one was genotype no.13 (1.78 t. acre $\left.{ }^{-1}\right)$ gave the highest LAI, which agrees with those results by Dwyer et al. (2001), while it disagreed with those reported by Gouis (1992). This genotype besides genotype no.4 (1.7 t. acre $\left.{ }^{-1}\right)$ gave the highest biological and straw yields, respectively. These results were in agreement with those of Noaman et al. (1997), Afiah and Moselhey (2001), and Assad et al. (1998). The seasonal effect on grain yield was clearly obvious as it is shown in Tables 14 and 17. The results declared that the first season was significantly higher in grain yield recording about $1.8 \mathrm{t}_{\text {acre }}{ }^{-1}$ compared to $1.0 \mathrm{t}$ $\mathrm{acre}^{-1}$ in the second season. This could be due to some differences in the rain fall pattern with higher amount of rain occurred during the growing season of the first season, which had positive effect on grain yield and also on biological and straw yields. This variation between the seasons concerning grain yield is confirmed by number of literatures, i.e., Jackson et al. (1994), Noaman et al. (1997) and Dwyer et al. (2001).

\subsection{Grain Protein Percent}

Protein percent of barley grains was measured in the 16 barley genotypes. Results shown in Table 13 reveal significant differences among all barley genotypes across the two seasons in addition to the second season, where the highest percent protein was detected for genotype no. 10 (16.1\%) followed by no. 5 (14\%) (Table 18). On the average, genotype no. 10 had the highest percent of protein recording $12.4 \%$ across the two seasons. On the other hand, the lowest protein \% was observed in genotype no. 15 with an average of $8.4 \%$ over the two seasons. The differences observed in grain protein among the present genotypes are in agreement with those obtained by Spoor and Simonds (1993) who revealed that there was a negative correlation between grain yield and its protein content. Table 14 shows that there was a significant seasonal effect and $(\mathrm{GxS})$ interaction concerning protein $\%$. On the average, data in Table 18 indicate that protein $\%$ in barley grains ranged between $8.3 \%$ and $11.8 \%$ in the first and second season, respectively. In this respect, this result was in agreement with that of Pecio et al. (2005).

\section{Conclusion}

It could be concluded that there was an interaction between genotypes and environment as was expected for grain protein trait with genotype no. 10 (80-5145/Hma-01/3/Arar/19-3//W12291) having the highest protein percentage overall cultivars and environments. It is one of ICARDA's promising lines, which was tested in Barley Research Department for more than 3 years in micro- and macro-yield trials. It was concluded from this investigation that there were four barley genotypes including genotypes no. 11, 13, 4, and 12 out yielded the three check cultivars in grain and biological yield significantly. They also have some other advantages such as earliness, harvest index, leaf area index, and higher protein content. It is suggested that those four genotypes could have more genetic stability studies to be grown in such calcareous soils.

\section{References}

Afiah, S.A.N., and Moselhy, N.M.M. (2001). Evaluation of selected barley genotypes under rainfed conditions of Ras El-Hekma, North Western Coast, Egypt. Annals of Agricultural Science, Cairo. (2001). 46(2):619-629.

Afiah, S.A.N., Sallam, H.A. and Khattab, S.A.M. (1999). Evaluation of divergent barley (Hordeum vulgare L.) genotypes under certain environments. Annals of Agricultural Science, Moshtohor. (1999): 37(2):973-988.

Afifi, H.A.A. (1999). Evaluation of some barley genotypes to drought tolerance. M.Sc. thesis, Fac. of Agric, Al-Azhar Univ, Egypt.

Assad, F.A., Noaman, M.M. Elsayed A.A. and Elbawab, A.O. (1998). Developing high-yielding barley cultivars under different stress conditions in Egypt. Egyptian Journal of Agricultural Research, 76(3):1037-1061.

Dwyer, L.M., Ma, L.B., Choo, T.M., Ho, K.M., Martin R.A. and Fregeau, J. (2001). Utilization of physiological traits for selection of high-yielding double haploid barley. Canadian Journal of Plant Science, 81(4):587-594.

Egan, H., Kirk, R.S., and Sawyer. R. (1981). Pearson's chemical analysis of foods $8^{\text {th }}$ Ed., Churchill Kiving Stone, Edinburg, London Melbourne and New York.

El-Hindi, M.H, El-Kassabey, A.T., Sharief, A.E. and Amer, K.A. (1998). Yield of barley as affected by different sources and levels of nitrogen fertilization under the environmental conditions of newly reclaimed soils at northern delta of Egypt .Proc. $8^{\text {th }}$ winter barley in rainfed conditions of the Central Anatolian Region. Journal of Crop Research/Bitkisel Arastirma Dergisi, 1(1):11-16. 
Ellen, J. (1993). Growth, yield and composition of four winter cereals. I. Biomass, grain yield and yield formation. Netherlands Journal of Agricultural Science, 1993; 41(2):153-165.

El-Sayed, A.A, Noaman, M.M. Asaad, F.A. El-Sherbini, A.M. El-Gamal, A.S. El-Bawab, A.M.O. El-Moselhy, M.A. Megahed, M.A. Abd El-Hamid M.M. and El-Desouki E.E. (1995). Giza 127 and Giza 128, new two rowed barley cultivars. Egypt. Appl. Sci., 10 (9): 466-476.

Ghasemi, A.K. (2001). The study on multiple regressions of various characters of yield components in different cultivars of barley (Hordeum vulgare L.). Journal of Agricultural Sciences, Islamic Azad University. 7(2): 61-78, en 5-6.

Gontia, A.S and Khare, A.K. (1992). Optimum leaf area index of barley (Hordeum vulgare L.) genotypes under various planting patterns. Advances in Plant Sciences, 1992; 5(1):43-52.

Gouis, J-le. (1992). A comparison between two- and six-row winter barley genotypes for above-ground dry matter production and distribution. Agronomie, 1992; 12(2):163-171.

Hradecka, D. (1994). Influence of alginate application on growth and yield formation of malting spring barley. Sbornik Vysoke Skoly Zemedelske-v Praze, Fakulta-Agronomicka Rada A, Rostlinna Vyroba. 1994; (56):79-85.

Jackson, P.A., Byth, D.E. Fischer, K.S. and Johnston, R.P. (1994). Genotype x environment interaction in progeny from barley cross variation in grain Yield, Yield components and dry matter Production among lines with similar times to anthesis. Field Crops Res. (37), Issue 1, April 1994:11-23.

Jamieson, P.D., Martin, R.J. Francis, G.S. and Wilson, D.R. (1994). Drought effects on biomass production in barley. Proceedings of Annual Conference of Agronomy Society of New Zealand. 1994; (24):129-130.

Jaskiewicz, B. (2008). Index LAI and SPAD of spring barley cultivars group depending on plant density. Folia Universitatis Agriculturae Stetinensis, Agricultura, Alimentaria, Piscaria ET-Zootechnica. 2008; 260 (5):37-42.

Kozowska, Ptaszynska. Z. (1995). Structure and output of the multi-row spring barley canopy under different nitrogen rates and plant densities. Pamietnik Puawski, 1995. (106):9-22.

Li, C.D., S.R. Din, X.L.Yie and R.P. Huang. (1991). Analysis of two-rowed barley ideotype breeding in the lower Yangtze valley. Acta Agriculturae Shanghai, 7(3):23-28.

Mansour, A.A. (1992). Study on drought tolerance in some barley genotypes. Azhar Univ. Cairo. Egypt. Fac. of Agric. Ph.D. Thesis in Agron.

Noaman, M.M, El-Sayed, A.A., Asaad, F.A.A., El-Sherbini, A.M., El-Bawab, A.O., El-Moselhi, M.A., and Rizk, R.A. (1995a). Registration of Giza 125, Barley. Crop Sci., 35:1709.

Noaman, M.M, El-Sayed, A.A., Asaad, F.A.A., El-Sherbini, A.M., El-Bawab, A.O., El-Moselhi, M.A. and Rizk, R.A. (1995b). Registration of Giza 126, Barley. Crop Sci., 35:1710.

Noaman, M.M, Asaad, F.A.A., El-Sayed, A.A., and El-bawab, A.M.O. (1997). Drought tolerant barley genotypes for rainfed areas in Egypt. Egyptian Journal of Agricultural Research, 1997; 75(4):1019-1036.

Oboda, T., Pietkiewicz, S., Czembor, H.J., and Wiewiora, M. (2000). Determination of yield potential of selected spring malting barley varieties. Biuletyn Instytutu Hodowli Aklimatyzacji Roslin. 2000. (215):141-152.

Oscarsson, M, R. Andersson, P. Aman, S. Olofsson and A. Jonsson. (1998). Effects of cultivar, nitrogen fertilization rate and environment on yield and grain quality of barley. J. of the Sci. of food and Agric, 78 (3):359-366. (CD Computer Room).

Pecio, A., Kubsik, K., and Bichonski, A. (2005). The reasons of grain yield and quality variation in a production field of spring barley. Biuletyn Instytutu Hodowli Aklimatyzacji Roslin, 2005. (236):157-166.

Sammis, T.W., Williams, S., Smeal, D., and Kallsen, C.E. (1986). Effect of soil moisture stress on leaf area index, evapotranspiration and modeled soil evaporation and transpiration. Transactions of the ASAE, American Society of Agricultural Engineers, 1986; 29(4):956-961.

Singh, S.S. (1989). Interrelationship between yield and sown quantitative characters in hull-less barley grown in saline alkaline conditions. Barley and wheat Newsletter, (8), No.1:196-210.

Spoor, W., and Simmonds, N.W. (1993). Pot trials as an adjunct to cereal breeding and evaluation of genetic resources. Field crops research, December 1993 (35), Issue 3: 205-213.

Spunarova, M., and Zenisceva, L. (1985). The effect of nitrogen and soil moisture contents on leaf area index, productivity and yield of spring barley. Rostlinna-Vyroba. 1985; 31(4):417-424. 
Steel, R.G.D., and Torrie, J.H. (1982). Principles and Procedures of statistics, $2^{\text {nd }}$ ed. McGrow-Hill Book Co., New York.

Weston, D.T, Horsley, R.D., Schwarz P.B., and Goos, R.J. (1993). Nitrogen and planting date effects on low protein spring barley. Agron J., 85 (6): 1170-1174.

Table 1. Soil physical and chemical properties of soil sampled from the field experimental site during the two consecutive seasons; 2005-06 and 2006-07.

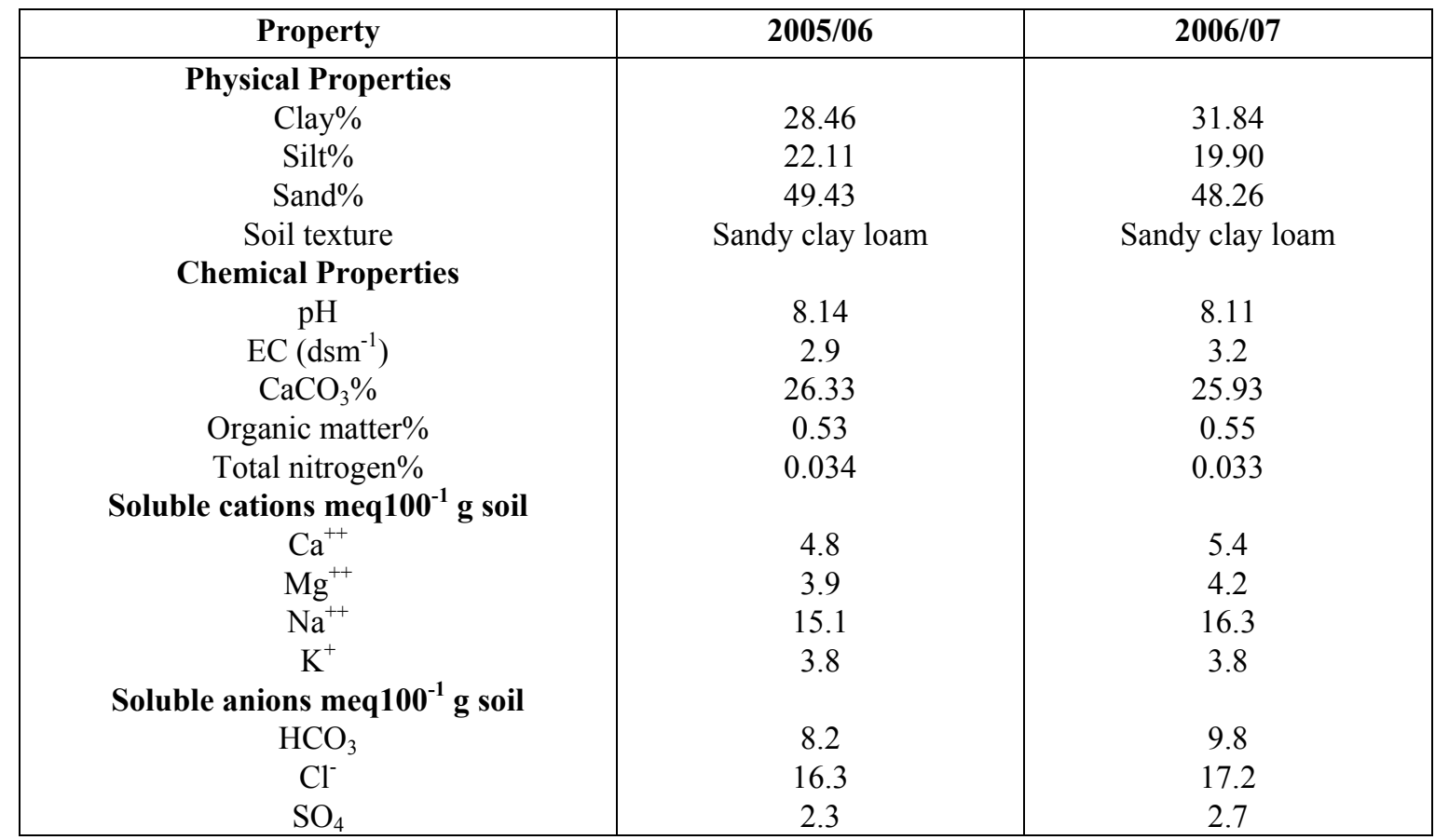

Table 2. Name and pedigree of barley cultivars and lines included in the field experiment

\begin{tabular}{|c|c|c|}
\hline No & Name \& Pedigree & Source \\
\hline .1 & Giza 123 & Barley Res. Dep. \\
\hline .2 & Giza 126 & Barley Res. Dep. \\
\hline .3 & Giza 2000 & Barley Res. Dep. \\
\hline .4 & Alanda/ Harma// Alanda 01 & B-5 2004/05 (B.R.D.) \\
\hline .5 & Rihance/Giza123 (1925) & B-8 2004/05 (B.R.D.) \\
\hline .6 & Rihance/Giza123 (1925) & B-9 2004/05 (B.R.D.) \\
\hline .7 & Aths/Lignee86//ACSAD68 & B-10 2004/05 (B.R.D.) \\
\hline .8 & Aths/Lignee86//ACSAD410 & B-12 2004/05 (B.R.D.) \\
\hline .9 & Nigrate/5/W12198/4/Attiki//Avt/Toi/82/Vt(Sel.2.2) & B-15 2004/05 (B.R.D.) \\
\hline .10 & 80-5145/Hma-01/3/Arar/19-3//W12291 & B-19 2004/05 (B.R.D.) \\
\hline .11 & Malouk//Aths/Linee686 & B-20 2004/05 (B.R.D.) \\
\hline .12 & Alanda/3/CI08887/CI05761//Lignee640/4/Alanda/Lossaika & B-22 2004/05 (B.R.D.) \\
\hline .13 & $\begin{array}{l}\text { Alanda-02/4/Arizona5908/Aths//Asse/3/F208-74/5/Alanda/3/CI088 } \\
\text { 87/C105761//Lignee640 }\end{array}$ & B-23 2004/05 (B.R.D.) \\
\hline .14 & Lignee527/NK1272//Alanda & B-24 2004/05 (B.R.D.) \\
\hline .15 & CL10114/Attiki//NK1272/3/Mzq/CI03909-2//Aths & B-26 2004/05 (B.R.D.) \\
\hline .16 & $\begin{array}{l}\text { Giza124/7/Man/Huiz//M69-69/3/Apm/RI//H272/4/ } \\
\text { CP/Bra/5/Joso‘S'/6/Chn-01/W12291 }\end{array}$ & B-27 2004/05 (B.R.D.) \\
\hline
\end{tabular}


Table 3. Mean square of days to heading and plant height of 16 barley genotypes in 2005/06 and 2006/07 growing seasons

\begin{tabular}{|c|c|c|c|c|c|c|c|}
\hline \multirow{3}{*}{ S.O.V } & \multirow{3}{*}{ D.F } & \multicolumn{3}{|c|}{ Days to heading } & \multicolumn{3}{|c|}{ Plant height } \\
\hline & & \multicolumn{2}{|c|}{ Season } & \multirow{2}{*}{ نٌ } & \multicolumn{2}{|c|}{ Season } & \multirow{2}{*}{ 异 } \\
\hline & & 2005/06 & 2006/07 & & $2005 / 06$ & 2006/07 & \\
\hline Rep. & 2 & 16.19 & 7.27 & ----- & 17.02 & 109.89 & ----- \\
\hline Genotype & 15 & 101.42 NS & $36.75 * *$ & $107.76^{* *}$ & $243.86 * *$ & 129.69 NS & $224.79 * *$ \\
\hline Error & 30 & 67.25 & 6.00 & 36.63 & 25.86 & 111.56 & 68.71 \\
\hline
\end{tabular}

*,** Significant at 0.05 and 0.01 level of probability, respectively.

$\mathrm{NS}=$ Not significant at 0.05 level of probability.

Table 4. Mean square of days to heading and plant height of 16 barley genotypes combined over the two seasons

\begin{tabular}{|c|c|c|c|}
\hline S.O.V & D.F & Days to heading & Plant height \\
\hline Season (S) & 1 & $48.166 \mathrm{NS}$ & $178.760 \mathrm{NS}$ \\
\hline SxRep & 4 & $11.729 \mathrm{NS}$ & $63.458 \mathrm{NS}$ \\
\hline Genotype & 15 & $107.756 * *$ & $224.788^{* *}$ \\
\hline SxG & 15 & $30.411 \mathrm{NS}$ & $148.760 * *$ \\
\hline Error & 60 & 36.629 & 68.714 \\
\hline
\end{tabular}

*, ** Significant at 0.05 and 0.01 level of probability, respectively.

NS = Not significant at 0.05 level of probability.

Table 5. Mean square of leaf area index (LAI) and number of grains spike ${ }^{-1}$ of 16 barley genotypes in 2005/06 and 2006/07 growing seasons

\begin{tabular}{|c|c|c|c|c|c|c|c|}
\hline \multirow{3}{*}{ S.O.V } & \multirow{3}{*}{ D.F. } & \multicolumn{3}{|c|}{ Leaf area index } & \multicolumn{3}{|c|}{$\begin{array}{c}\text { Number } \\
\text { of grains spike }^{-1}\end{array}$} \\
\hline & & \multicolumn{2}{|c|}{ Season } & \multirow{2}{*}{ 导 } & \multicolumn{2}{|c|}{ Season } & \multirow{2}{*}{ 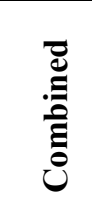 } \\
\hline & & $2005 / 06$ & $2006 / 07$ & & $2005 / 06$ & 2006/07 & \\
\hline Rep. & 2 & 0.004 & 0.002 & ----- & 6.636 & 22.504 & ----- \\
\hline Genotype & 15 & $\begin{array}{l}0.468 \\
* *\end{array}$ & $0.237 * *$ & $\begin{array}{c}0.58 \\
* *\end{array}$ & $\begin{array}{c}57.54 \\
\mathrm{NS}\end{array}$ & $135.28 * *$ & $\begin{array}{c}84.76 \\
*\end{array}$ \\
\hline Error & 30 & 0.06 & 0.05 & 0.05 & 41.45 & 41.76 & 41.61 \\
\hline
\end{tabular}

$*$, ** Significant at 0.05 and 0.01 level of probability, respectively.

$\mathrm{NS}=$ Not significant at 0.05 level of probability. 
Table 6. Mean square of leaf area index (LAI) and number of grains spike ${ }^{-1}$ of 16 barley genotypes combined over the two seasons

\begin{tabular}{|c|c|c|c|}
\hline S.O.V & D.F & Leaf area index & $\begin{array}{c}\text { Number } \\
\text { of grains spike }\end{array}$ \\
\hline Season (S) & 1 & $2.95 * *$ & $1332.21 * *$ \\
\hline S x Rep & 4 & $0.02 \mathrm{~ns}$ & $14.57 \mathrm{~ns}$ \\
\hline Genotype & 15 & $0.58 * *$ & $84.77 *$ \\
\hline S x G & 15 & $0.12 *$ & $108.05 * *$ \\
\hline Error & 60 & 0.05 & 41.61 \\
\hline
\end{tabular}

*, ** Significant at 0.05 and 0.01 level of probability, respectively.

$\mathrm{NS}=$ Not significant at 0.05 level of probability.

Table 7. Mean square of spike weight (g) and 1000-kernel weight (g) of 16 barley genotypes for 2005/2006 and 2006/2007 growing seasons

\begin{tabular}{|c|c|c|c|c|c|c|c|}
\hline \multirow{3}{*}{ S.O.V } & \multirow{3}{*}{ D.F } & \multicolumn{3}{|c|}{$\begin{array}{c}\text { Spike weight } \\
\text { (g) }\end{array}$} & \multicolumn{3}{|c|}{ 1000-kernel weight (g) } \\
\hline & & \multicolumn{2}{|c|}{ Season } & \multirow{2}{*}{ 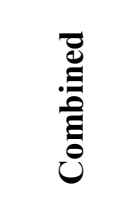 } & \multicolumn{2}{|c|}{ Season } & \multirow{2}{*}{ 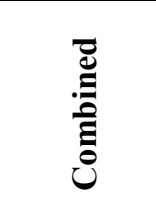 } \\
\hline & & 2005/06 & 2006/07 & & 2005/06 & 2006/07 & \\
\hline Rep. & 2 & 0.325 & 0.039 & ----- & 0.083 & 2.275 & ----- \\
\hline Genotype & 15 & $0.628^{* *}$ & $0.449 * *$ & $0.573 * *$ & $43.988 * *$ & $81.770 * *$ & $107.065^{* *}$ \\
\hline Error & 30 & 0.118 & 0.159 & 0.139 & 6.146 & 12.512 & 9.329 \\
\hline
\end{tabular}

*, ** Significant at 0.05 and 0.01 level of probability, respectively.

NS $=$ Not significant at 0.05 level of probability.

Table 8. Mean square of spike weight (g) and 1000-kernel weight (g) of 16 barley genotypes combined over the two seasons

\begin{tabular}{|c|c|c|c|}
\hline S.O.V. & D.F. & Spike weight (g) & 1000-kernel weight (g) \\
\hline Season (S) & 1 & $0.900^{*}$ & $2196.315^{* *}$ \\
\hline SxRep & 4 & $0.181 \mathrm{~ns}$ & $1.179 \mathrm{~ns}$ \\
\hline Genotype & 15 & $0.573^{* *}$ & $107.065^{* *}$ \\
\hline SxG & 15 & $0.504^{* *}$ & $18.693^{*}$ \\
\hline Error & 60 & 0.139 & 9.329 \\
\hline
\end{tabular}

$*, * *$ Significant at 0.05 and 0.01 level of probability, respectively.

NS $=$ Not significant at 0.05 level of probability. 
Table 9. Mean square of number of spikes $\mathrm{m}^{-2}$ and biological yield ( $\mathrm{t}$ acre ${ }^{-1}$ ) of 16 barley genotypes for $2005 / 06$ and 2006/07 growing seasons

\begin{tabular}{|c|c|c|c|c|c|c|c|}
\hline \multirow{3}{*}{ S.O.V. } & \multirow{3}{*}{ D.F. } & \multicolumn{3}{|c|}{ Number of spikes $\mathbf{m}^{-2}$} & \multicolumn{3}{|c|}{ Biological yield ( $t$ acre-1) } \\
\hline & & \multicolumn{2}{|c|}{ Season } & \multirow{2}{*}{ 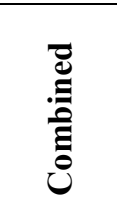 } & \multicolumn{2}{|c|}{ Season } & \multirow[b]{2}{*}{ ن } \\
\hline & & $2005 / 06$ & 2006/07 & & $2005 / 06$ & $2006 / 07$ & \\
\hline Rep. & 2 & 2003.5 & 193.0 & ----- & 0.28 & 0.45 & ---- \\
\hline Genotype & 15 & $\begin{array}{c}3420.8 \\
*\end{array}$ & $\begin{array}{c}1229.3 \\
\text { NS }\end{array}$ & $\begin{array}{c}2603.9 \\
*\end{array}$ & $\begin{array}{c}4.02 \\
* *\end{array}$ & $\begin{array}{c}1.72 \\
* *\end{array}$ & $\begin{array}{c}4.30 \\
* *\end{array}$ \\
\hline Error & 30 & 1306.8 & 1252.9 & 1279.8 & 0.14 & 0.58 & 0.36 \\
\hline
\end{tabular}

*,** Significant at 0.05 and 0.01 level of probability, respectively.

$\mathrm{NS}=$ Not significant at 0.05 level of probability.

Table 10. Mean square of number of spikes $\mathrm{m}^{-2}$ and biological yield $\left(\mathrm{t}\right.$ acre $\left.^{1}\right)$ of 16 barley genotypes combined over the two seasons

\begin{tabular}{|c|c|c|c|}
\hline S.O.V & D.F & Number of spikes $\mathbf{~ m}^{-2}$ & ${\text { Biological yield(t } \text { acre }^{-\mathbf{1}} \text { ) }}^{\text {Season (S) }}$ \\
\hline S x Rep & 1 & $233248.16^{* *}$ & $117.22^{* *}$ \\
\hline Genotype & 15 & $1098.29 \mathrm{NS}$ & $0.37 \mathrm{NS}$ \\
\hline S x G & 15 & $2603.90 *$ & $4.30^{* *}$ \\
\hline Error & 60 & $2046.30 \mathrm{NS}$ & $1.44^{* *}$ \\
\hline
\end{tabular}

*, ** Significant at 0.05 and 0.01 level of probability, respectively.

$\mathrm{NS}=$ Not significant at 0.05 level of probability.

Table 11. Mean square of straw yield $\left(\mathrm{t}_{\mathrm{acre}}{ }^{-1}\right)$ and harvest index (HI) of 16 barley genotypes for 2005/06 and 2006/07 growing seasons

\begin{tabular}{|c|c|c|c|c|c|c|c|}
\hline \multirow[b]{3}{*}{ S.O.V. } & \multirow[b]{3}{*}{ D.F. } & \multicolumn{3}{|c|}{ Straw yield ( $\mathbf{t}$ acre $^{-1}$ ) } & \multicolumn{3}{|c|}{ Harvest Index (HI) } \\
\hline & & \multicolumn{2}{|c|}{ Season } & \multirow[b]{2}{*}{ 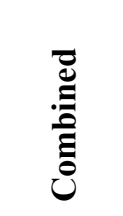 } & \multicolumn{2}{|c|}{ Season } & \multirow[b]{2}{*}{ 㞧 } \\
\hline & & $2005 / 06$ & 2006/07 & & $2005 / 06$ & 2006/07 & \\
\hline Rep. & 2 & 0.29 & 0.14 & ----- & 8.49 & 39.54 & ----- \\
\hline Genotype & 15 & $2.34 * *$ & $1.09 * *$ & $2.53 * *$ & $16.64 \mathrm{NS}$ & $44.58 *$ & $31.94 * *$ \\
\hline Error & 30 & 0.11 & 0.33 & 0.22 & 9.12 & 17.32 & 13.22 \\
\hline
\end{tabular}

*, ** Significant at 0.05 and 0.01 level of probability, respectively.

NS = Not significant at 0.05 level of probability. 
Table 12. Mean square of straw yield $\left(\mathrm{tacre}^{-1}\right)$ and harvest index of 16 barley genotypes combined over the two seasons

\begin{tabular}{|c|c|c|c|}
\hline S.O.V & D.F. & Straw yield $\left(\mathbf{t ~ a c r e}^{-\mathbf{1}}\right)$ & Harvest Index (HI) \\
\hline Season (S) & 1 & $44.64^{* *}$ & $566.63^{* *}$ \\
\hline S x Rep & 4 & $0.21 \mathrm{~ns}$ & $24.02 \mathrm{~ns}$ \\
\hline Genotype & 15 & $2.53^{* *}$ & $31.94^{* *}$ \\
\hline S x G & 15 & $0.90^{* *}$ & $29.27^{*}$ \\
\hline Error & 60 & 0.22 & 13.22 \\
\hline
\end{tabular}

*, ** Significant at 0.05 and 0.01 level of probability, respectively.

$\mathrm{NS}=$ Not significant at 0.05 level of probability.

Table 13. Mean square of grain yield $\left(\mathrm{t}\right.$ acre $\left.{ }^{-1}\right)$ and grain protein percent of 16 barley genotypes for 2005/2006 and 2006/2007 growing seasons

\begin{tabular}{|c|c|c|c|c|c|c|c|}
\hline \multirow{3}{*}{ S.O.V. } & \multirow{3}{*}{ D.F. } & \multicolumn{3}{|c|}{ Grain yield (t acre $\left.^{-1}\right)$} & \multicolumn{3}{|c|}{ Grain protein percent } \\
\hline & & \multicolumn{2}{|c|}{ Season } & \multirow{2}{*}{ 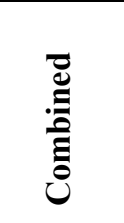 } & \multicolumn{2}{|c|}{ Season } & \multirow{2}{*}{ 总 } \\
\hline & & 2005/06 & 2006/07 & & $2005 / 06$ & 2006/07 & \\
\hline Rep. & 2 & 0.02 & 0.17 & ----- & 0.81 & 2.85 & ---- \\
\hline Genotype & 15 & $0.31 * *$ & $0.15 * *$ & $0.32 * *$ & $0.97 \mathrm{NS}$ & $11.63 *$ & $5.98 *$ \\
\hline Error & 30 & 0.04 & 0.04 & 0.04 & 0.97 & 5.51 & 3.24 \\
\hline
\end{tabular}

*, ** Significant at 0.05 and 0.01 level of probability, respectively.

NS $=$ Not significant at 0.05 level of probability.

Table 14. Mean squares of grain yield $\left(\mathrm{t}\right.$ acre $\left.{ }^{-1}\right)$ and grain protein percent of 16 barley genotypes combined over the two seasons

\begin{tabular}{|c|c|c|c|}
\hline S.O.V & D.F & Grain yield & Grain protein percent \\
\hline Season (S) & 1 & $17.21 * *$ & $292.43 * *$ \\
\hline S x Rep & 4 & $0.09 \mathrm{NS}$ & $1.83 \mathrm{NS}$ \\
\hline Genotype & 15 & $0.32 * *$ & $5.99 *$ \\
\hline S x G & 15 & $0.13 * *$ & $6.622 *$ \\
\hline Error & 60 & 0.04 & 3.24 \\
\hline
\end{tabular}

*, ** Significant at 0.05 and 0.01 level of probability, respectively.

$\mathrm{NS}=$ Not significant at 0.05 level of probability. 
Table 15. Means of plant height, leaf area index and days to heading as affected by various genotypes of barley during 2005/06 and2006/07 growing seasons

\begin{tabular}{|c|c|c|c|c|c|c|c|c|c|}
\hline \multirow{2}{*}{ Genotype } & \multicolumn{3}{|c|}{ Plant height (cm) } & \multicolumn{3}{|c|}{ Leaf area index } & \multicolumn{3}{|c|}{ Days to heading } \\
\hline & $2005 / 06$ & 2006/07 & Combined & $2005 / 06$ & 2006/07 & Combined & 2005/06 & 2006/07 & Combined \\
\hline 1 & $105.7 \mathrm{c}$ & $103.3 \mathrm{abc}$ & $104.5 \mathrm{bc}$ & $3.2 \mathrm{bc}$ & $2.6 \mathrm{bc}$ & $2.9 \mathrm{c}$ & $91.3 \mathrm{ab}$ & $91.0 \mathrm{a}$ & $91.2 \mathrm{a}$ \\
\hline 2 & $106.3 \mathrm{bc}$ & $106.7 \mathrm{ab}$ & $106.5 \mathrm{ab}$ & $3.6 \mathrm{a}$ & $2.7 \mathrm{ab}$ & $3.2 \mathrm{ab}$ & $84.3 \mathrm{abc}$ & $88.0 \mathrm{ab}$ & $86.2 \mathrm{ab}$ \\
\hline 3 & $115.7 \mathrm{a}$ & $113.3 \mathrm{a}$ & $114.5 \mathrm{a}$ & $3.1 \mathrm{bcd}$ & $2.7 \mathrm{ab}$ & $2.9 \mathrm{bc}$ & $90.7 \mathrm{ab}$ & $90.0 \mathrm{ab}$ & $90.3 \mathrm{ab}$ \\
\hline 4 & $104.7 \mathrm{c}$ & $93.3 \mathrm{bc}$ & 99.0 bcde & 2.9 cdefg & 2.3 cde & $2.6 \mathrm{defg}$ & $92.7 \mathrm{ab}$ & $91.0 \mathrm{a}$ & $91.8 \mathrm{a}$ \\
\hline 5 & $104.0 \mathrm{~cd}$ & $108.3 \mathrm{ab}$ & $106.2 \mathrm{ab}$ & 2.8 defgh & $2.3 \mathrm{cde}$ & 2.5 defgh & $92.0 \mathrm{ab}$ & $86.0 \mathrm{abc}$ & $89.0 \mathrm{ab}$ \\
\hline 6 & $105.7 \mathrm{c}$ & $101.7 \mathrm{abc}$ & $103.7 \mathrm{bc}$ & 2.5 ghij & $2.0 \mathrm{e}$ & $2.3 \mathrm{ij}$ & $91.0 \mathrm{ab}$ & $86.0 \mathrm{abc}$ & $88.5 \mathrm{ab}$ \\
\hline 7 & $95.0 \mathrm{ef}$ & $95.0 \mathrm{bc}$ & $95.0 \mathrm{cde}$ & $3.0 \mathrm{bcdef}$ & $2.6 \mathrm{bcd}$ & $2.8 \mathrm{~cd}$ & $89.7 \mathrm{ab}$ & $82.7 \mathrm{bc}$ & $86.2 \mathrm{ab}$ \\
\hline 8 & $86.7 \mathrm{fg}$ & $96.7 \mathrm{abc}$ & $91.7 \mathrm{de}$ & 2.6 efghi & $2.1 \mathrm{e}$ & 2.4 ghij & $87.0 \mathrm{ab}$ & $84.0 \mathrm{abc}$ & $85.5 \mathrm{ab}$ \\
\hline 9 & $114.7 \mathrm{ab}$ & $86.7 \mathrm{c}$ & $100.7 \mathrm{bcd}$ & $2.3 \mathrm{ij}$ & $2.3 \mathrm{de}$ & $2.3 \mathrm{hij}$ & $93.7 \mathrm{ab}$ & $88.0 \mathrm{ab}$ & $90.8 \mathrm{a}$ \\
\hline 10 & $95.3 \mathrm{e}$ & $95.0 \mathrm{bc}$ & 95.2 cde & 3.0 bcde & $2.5 \mathrm{bcd}$ & $2.8 \mathrm{cde}$ & $87.0 \mathrm{ab}$ & $88.3 \mathrm{ab}$ & $87.7 \mathrm{ab}$ \\
\hline 11 & $86.0 \mathrm{~g}$ & $95.0 \mathrm{bc}$ & $90.5 \mathrm{e}$ & 2.7 efghi & $2.7 \mathrm{ab}$ & $2.7 \mathrm{cdef}$ & $80.0 \mathrm{bc}$ & $85.7 \mathrm{abc}$ & $82.8 \mathrm{bc}$ \\
\hline 12 & 94.7 ef & $100.0 \mathrm{abc}$ & 97.3 bcde & 2.6 fghij & $2.3 \mathrm{cde}$ & 2.4 fghij & $96.0 \mathrm{a}$ & $88.7 \mathrm{ab}$ & $92.3 \mathrm{a}$ \\
\hline 13 & $95.7 \mathrm{de}$ & $103.3 \mathrm{abc}$ & 99.5 bcde & $3.3 \mathrm{ab}$ & $3.1 \mathrm{a}$ & $3.2 \mathrm{a}$ & $72.7 \mathrm{c}$ & $78.3 \mathrm{c}$ & $75.5 \mathrm{c}$ \\
\hline 14 & $110.7 \mathrm{abc}$ & $95.0 \mathrm{bc}$ & $102.8 \mathrm{bc}$ & $2.4 \mathrm{hij}$ & $2.6 \mathrm{bcd}$ & 2.5 efghi & $83.3 \mathrm{abc}$ & $87.3 \mathrm{ab}$ & $85.3 \mathrm{ab}$ \\
\hline 15 & $105.7 \mathrm{c}$ & $98.3 \mathrm{abc}$ & $102.0 \mathrm{bc}$ & 2.5 ghij & $2.2 \mathrm{de}$ & 2.4 ghij & $88.0 \mathrm{ab}$ & $82.3 \mathrm{bc}$ & $85.2 \mathrm{ab}$ \\
\hline 16 & 109.0abc & $100.0 \mathrm{abc}$ & $104.5 \mathrm{bc}$ & $2.2 \mathrm{~J}$ & $2.2 \mathrm{de}$ & $2.2 \mathrm{j}$ & $90.7 \mathrm{ab}$ & $90.0 \mathrm{ab}$ & $90.3 \mathrm{ab}$ \\
\hline Average & 102.2 & 99.5 & 100.8 & 2.8 & 2.4 & 2.6 & 88.1 & 86.7 & 87.4 \\
\hline LSD 0.05 & 8.5 & 17.6 & 9.6 & 0.39 & 0.37 & 0.30 & 13.7 & 8.26 & 7.8 \\
\hline CV\% & 5.0 & 10.6 & 8.2 & 8.5 & 9.1 & 8.8 & 9.3 & 5.7 & 7.75 \\
\hline
\end{tabular}

Means followed by the same letter within each column are not significantly different at 0.05 level of probability, according to LSD 0.05 . 
Table 16. Means of number of spikes $\mathrm{m}^{-2}$, number of grains spike $\mathrm{e}^{-1}$ and spike weight as affected by various genotypes of barley during 2005/06 and 2006/07 growing seasons

\begin{tabular}{|c|c|c|c|c|c|c|c|c|c|}
\hline \multirow[t]{2}{*}{ Genotype } & \multicolumn{3}{|c|}{ No. spikes $\mathbf{m}^{-2}$} & \multicolumn{3}{|c|}{ No. grains Spk ${ }^{-1}$} & \multicolumn{3}{|c|}{ Spike weight (g) } \\
\hline & $2005 / 06$ & 2006/07 & Combined & $2005 / 06$ & 2006/07 & Combined & 2005/06 & 2006/07 & Combined \\
\hline 1 & $358.0 \mathrm{ab}$ & $240.0 \mathrm{ab}$ & $299.0 \mathrm{a}$ & $60.3 \mathrm{a}$ & $48.1 \mathrm{bcdefg}$ & $54.2 \mathrm{abc}$ & 2.9 cdefg & $2.9 \mathrm{bcd}$ & $2.9 \mathrm{def}$ \\
\hline 2 & $300.0 \mathrm{bcd}$ & $236.0 \mathrm{ab}$ & $268.0 \mathrm{abc}$ & $52.5 \mathrm{ab}$ & $57.4 \mathrm{ab}$ & $54.9 \mathrm{abc}$ & $2.5 \mathrm{~g}$ & $3.3 \mathrm{ab}$ & $2.9 \mathrm{def}$ \\
\hline 3 & $336.7 \mathrm{abc}$ & $217.3 \mathrm{ab}$ & $277.0 \mathrm{abc}$ & $59.9 \mathrm{a}$ & $37.4 \mathrm{~g}$ & $48.7 \mathrm{c}$ & $3.9 \mathrm{a}$ & $2.5 \mathrm{~cd}$ & $3.2 \mathrm{bcd}$ \\
\hline 4 & $310.0 \mathrm{abcd}$ & $250.7 \mathrm{ab}$ & $280.3 \mathrm{abc}$ & $62.2 \mathrm{a}$ & $53.4 \mathrm{~cd}$ & $57.8 \mathrm{ab}$ & 3.2 bcde & $2.9 \mathrm{bcd}$ & $3.1 \mathrm{~cd}$ \\
\hline 5 & $344.7 \mathrm{abc}$ & $216.0 \mathrm{ab}$ & $280.3 \mathrm{abc}$ & $56.3 \mathrm{ab}$ & $53.7 \mathrm{abc}$ & $55.0 \mathrm{abc}$ & $2.6 \mathrm{fg}$ & $3.1 \mathrm{abc}$ & $2.9 \mathrm{def}$ \\
\hline 6 & $254.7 \mathrm{~d}$ & $238.7 \mathrm{ab}$ & $246.7 \mathrm{bc}$ & $54.6 \mathrm{ab}$ & 42.4 efg & $48.5 \mathrm{c}$ & 3.2 bcde & $2.6 \mathrm{~cd}$ & $2.9 \mathrm{def}$ \\
\hline 7 & $336.7 \mathrm{abc}$ & $252.0 \mathrm{a}$ & $294.3 \mathrm{a}$ & $52.4 \mathrm{ab}$ & 51.1 abcdef & $51.7 \mathrm{bc}$ & $3.2 \mathrm{bcdef}$ & $3.0 \mathrm{bcd}$ & $3.1 \mathrm{~cd}$ \\
\hline 8 & $288.7 \mathrm{~cd}$ & $192.0 \mathrm{~b}$ & $240.3 \mathrm{c}$ & $54.9 \mathrm{ab}$ & 47.4 bcdefg & $51.2 \mathrm{bc}$ & $3.4 \mathrm{abc}$ & $2.6 \mathrm{~cd}$ & $3.0 \mathrm{de}$ \\
\hline 9 & $342.0 \mathrm{abc}$ & $217.3 \mathrm{ab}$ & $279.7 \mathrm{abc}$ & $52.9 \mathrm{ab}$ & 44.4 cdefg & $48.7 \mathrm{c}$ & $3.8 \mathrm{a}$ & $3.1 \mathrm{abc}$ & $3.5 \mathrm{abc}$ \\
\hline 10 & $336.0 \mathrm{abc}$ & $252.0 \mathrm{a}$ & $294.0 \mathrm{a}$ & $47.5 \mathrm{~b}$ & $53.4 \mathrm{abcd}$ & $50.4 \mathrm{bc}$ & $3.3 \mathrm{abcd}$ & $3.0 \mathrm{bcd}$ & $3.2 \mathrm{bcd}$ \\
\hline 11 & $366.0 \mathrm{a}$ & $210.7 \mathrm{ab}$ & $288.3 \mathrm{a}$ & $61.2 \mathrm{a}$ & $42.8 \mathrm{defg}$ & $52.0 \mathrm{bc}$ & $2.8 \mathrm{defg}$ & $2.4 \mathrm{~d}$ & $2.6 \mathrm{f}$ \\
\hline 12 & $348.0 \mathrm{abc}$ & $226.7 \mathrm{ab}$ & $287.3 \mathrm{ab}$ & $58.5 \mathrm{a}$ & $60.5 \mathrm{a}$ & $59.5 \mathrm{a}$ & $3.7 \mathrm{ab}$ & $3.7 \mathrm{a}$ & $3.7 \mathrm{a}$ \\
\hline 13 & $272.0 \mathrm{~d}$ & $208.0 \mathrm{ab}$ & $240.0 \mathrm{c}$ & $55.9 \mathrm{ab}$ & 52.7 abcde & $54.3 \mathrm{abc}$ & $3.7 \mathrm{ab}$ & $3.4 \mathrm{ab}$ & $3.5 \mathrm{ab}$ \\
\hline 14 & $342.0 \mathrm{abc}$ & $253.0 \mathrm{a}$ & $297.7 \mathrm{a}$ & $58.7 \mathrm{a}$ & $41.8 \mathrm{fg}$ & $50.2 \mathrm{c}$ & $2.7 \mathrm{efg}$ & $2.4 \mathrm{~d}$ & $2.6 \mathrm{ef}$ \\
\hline 15 & $366.0 \mathrm{a}$ & $212.0 \mathrm{ab}$ & $289.0 \mathrm{a}$ & $61.6 \mathrm{a}$ & $59.1 \mathrm{a}$ & $60.4 \mathrm{a}$ & $2.7 \mathrm{efg}$ & $3.5 \mathrm{ab}$ & $3.1 \mathrm{~cd}$ \\
\hline 16 & $296.0 \mathrm{~cd}$ & $197.3 \mathrm{ab}$ & $246.7 \mathrm{bc}$ & $63.0 \mathrm{a}$ & 47.4 cdefg & $55.2 \mathrm{abc}$ & $2.7 \mathrm{efg}$ & $3.0 \mathrm{abcd}$ & $2.9 \mathrm{def}$ \\
\hline Average & 324.8 & 226.3 & 275.5 & 57.0 & 49.6 & 53.3 & 3.2 & 3.0 & 3.0 \\
\hline LSD 0.05 & 60.3 & 59.0 & 41.3 & 10.7 & 10.8 & 7.4 & 0.57 & 0.66 & 0.43 \\
\hline CV\% & 11.1 & 15.6 & 12.9 & 11.3 & 13.0 & 12.1 & 10.9 & 13.4 & 12.2 \\
\hline
\end{tabular}

Means followed by the same letter within each column are not significantly different at 0.05 level of probability, according to LSD 0.05 . 
Table 17. Means of 1000-kernel weight, biological yield and grain yield as affected by various genotypes of barley during 2005/06 and 2006/07 growing seasons

\begin{tabular}{|c|c|c|c|c|c|c|c|c|c|}
\hline \multirow{2}{*}{ Genotype } & \multicolumn{3}{|c|}{ 1000-kernel weight (g) } & \multicolumn{3}{|c|}{ Biological yield $\left(t\right.$ acre $\left.^{-1}\right)$} & \multicolumn{3}{|c|}{ Grain yield $\left(t\right.$ acre $\left.^{-1}\right)$} \\
\hline & $2005 / 06$ & 2006/07 & Combined & $2005 / 06$ & 2006/07 & Combined & $2005 / 06$ & 2006/07 & Combined \\
\hline 1 & 40.5 bcde & 50.4 cde & $45.7 \mathrm{cdef}$ & $4.43 \mathrm{f}$ & $4.16 \mathrm{bc}$ & $4.30 \mathrm{gh}$ & $1.44 \mathrm{c}$ & 0.96 cde & $1.20 \mathrm{hi}$ \\
\hline 2 & 37.3 ef & $48.2 \mathrm{defg}$ & 42.8 fghi & $5.26 \mathrm{cde}$ & $3.80 \mathrm{bc}$ & $4.53 \mathrm{fgh}$ & $1.52 \mathrm{c}$ & $0.73 \mathrm{e}$ & $1.13 \mathrm{i}$ \\
\hline 3 & $52.3 \mathrm{a}$ & $61.5 \mathrm{a}$ & $56.9 \mathrm{a}$ & $7.18 \mathrm{~b}$ & $3.19 \mathrm{c}$ & $5.19 \mathrm{def}$ & $1.76 \mathrm{bc}$ & $0.74 \mathrm{e}$ & $1.25 \mathrm{ghi}$ \\
\hline 4 & $37.3 \mathrm{ef}$ & $45.3 \mathrm{efg}$ & $41.3 \mathrm{hi}$ & $7.96 \mathrm{a}$ & $4.88 \mathrm{~b}$ & $6.42 \mathrm{~b}$ & $2.22 \mathrm{a}$ & $1.19 \mathrm{abc}$ & $1.70 \mathrm{abc}$ \\
\hline 5 & 40.0 bcde & $46.3 \mathrm{efg}$ & 43.2 efghi & $5.86 \mathrm{c}$ & $4.04 \mathrm{bc}$ & $4.95 \mathrm{efg}$ & $1.53 \mathrm{c}$ & 0.91 cde & $1.22 \mathrm{ghi}$ \\
\hline 6 & $42.0 \mathrm{bcd}$ & $48.7 \mathrm{defg}$ & 45.4 cdefg & $5.10 \mathrm{de}$ & $3.38 \mathrm{c}$ & $4.24 \mathrm{~h}$ & $1.52 \mathrm{c}$ & $0.81 \mathrm{de}$ & $1.17 \mathrm{hi}$ \\
\hline 7 & $39.5 \mathrm{cde}$ & 49.3 cdefg & 44.4 defgh & $7.08 \mathrm{~b}$ & $3.80 \mathrm{bc}$ & $5.44 \mathrm{cde}$ & $2.13 \mathrm{a}$ & 0.96 cde & 1.54 bcde \\
\hline 8 & 40.1 bcde & $49.9 \mathrm{cdef}$ & 45.0 cdefg & $7.27 \mathrm{~b}$ & $4.10 \mathrm{bc}$ & $5.69 \mathrm{~cd}$ & $2.08 \mathrm{ba}$ & $1.01 \mathrm{bcde}$ & $1.55 \mathrm{bcde}$ \\
\hline 9 & $44.0 \mathrm{~b}$ & $60.0 \mathrm{ab}$ & $52.0 \mathrm{~b}$ & $7.10 \mathrm{~b}$ & $3.80 \mathrm{bc}$ & $5.49 \mathrm{cde}$ & $2.21 \mathrm{a}$ & $0.78 \mathrm{de}$ & $1.50 \mathrm{cdef}$ \\
\hline 10 & $35.1 \mathrm{f}$ & $44.2 \mathrm{fg}$ & $39.6 \mathrm{i}$ & $5.07 \mathrm{ef}$ & $4.10 \mathrm{bc}$ & $4.59 \mathrm{fgh}$ & $1.66 \mathrm{c}$ & $1.12 \mathrm{abcd}$ & $1.40 \mathrm{eghf}$ \\
\hline 11 & $42.9 \mathrm{bcd}$ & 46.9 efg & $44.9 \mathrm{defg}$ & $7.05 \mathrm{~b}$ & $4.88 \mathrm{~b}$ & $5.94 \mathrm{bc}$ & $2.26 \mathrm{a}$ & $1.32 \mathrm{ab}$ & $1.79 \mathrm{a}$ \\
\hline 12 & 40.6 bcde & $43.5 \mathrm{~g}$ & 42.0 ghi & $7.08 \mathrm{~b}$ & $4.70 \mathrm{~b}$ & $5.85 \mathrm{bcd}$ & $2.17 \mathrm{a}$ & $1.18 \mathrm{abc}$ & $1.67 \mathrm{abcd}$ \\
\hline 13 & $38.9 \mathrm{def}$ & $49.1 \mathrm{cdefg}$ & $44.0 \mathrm{efgh}$ & $8.20 \mathrm{a}$ & $6.21 \mathrm{a}$ & $7.21 \mathrm{a}$ & $2.19 \mathrm{a}$ & $1.36 \mathrm{a}$ & $1.78 \mathrm{ab}$ \\
\hline 14 & 40.0 bcde & $55.0 \mathrm{bc}$ & $47.5 \mathrm{~cd}$ & $5.73 \mathrm{~cd}$ & $3.25 \mathrm{c}$ & $4.49 \mathrm{fgh}$ & $1.75 \mathrm{bc}$ & $0.80 \mathrm{de}$ & $1.27 \mathrm{fghi}$ \\
\hline 15 & $39.7 \mathrm{cde}$ & $53.4 \mathrm{~cd}$ & $46.6 \mathrm{cde}$ & $5.67 \mathrm{cde}$ & $3.77 \mathrm{bc}$ & $4.72 \mathrm{fgh}$ & $1.54 \mathrm{c}$ & $1.33 \mathrm{ab}$ & $1.44 \mathrm{defg}$ \\
\hline 16 & $43.0 \mathrm{bc}$ & $53.9 \mathrm{~cd}$ & $48.5 \mathrm{c}$ & $5.19 \mathrm{de}$ & $3.74 \mathrm{bc}$ & $4.47 \mathrm{gh}$ & $1.52 \mathrm{c}$ & $0.82 \mathrm{de}$ & $1.17 \mathrm{hi}$ \\
\hline Average & 40.8 & 50.4 & 45.6 & 6.3 & 4.1 & 5.2 & 1.8 & 1.0 & 1.4 \\
\hline LSD 0.05 & 4.1 & 5.9 & 3.5 & 0.64 & 1.27 & 0.70 & 0.34 & 0.34 & 0.24 \\
\hline CV\% & 6.0 & 7.0 & 6.7 & 6.0 & 18.5 & 11.5 & 11.0 & 20.5 & 14.3 \\
\hline
\end{tabular}

Means followed by the same letter within each column are not significantly different at 0.05 level of probability, according to LSD 0.05 . 
Table 18. Means of straw yield, harvest index and grain protein percent as affected by various genotypes of barley during 2005/06 and 2006/07 growing seasons

\begin{tabular}{|c|c|c|c|c|c|c|c|c|c|}
\hline \multirow{2}{*}{ Genotype } & \multicolumn{3}{|c|}{ Straw yield $\left(\mathrm{t}\right.$ acre $\left.^{-1}\right)$} & \multicolumn{3}{|c|}{ Harvest Index (HI) } & \multicolumn{3}{|c|}{ Grain protein percent } \\
\hline & $2005 / 06$ & 2006/07 & Combined & $2005 / 06$ & 2006/07 & Combined & $2005 / 06$ & 2006/07 & Combined \\
\hline 1 & $3.0 \mathrm{i}$ & $3.2 \mathrm{bc}$ & $3.1 \mathrm{f}$ & $32.4 \mathrm{a}$ & $23.1 \mathrm{bcd}$ & $27.7 \mathrm{abcd}$ & $8.0 \mathrm{abc}$ & $10.7 \mathrm{bcd}$ & $9.3 \mathrm{bc}$ \\
\hline 2 & $3.7 \mathrm{gh}$ & $3.1 \mathrm{bc}$ & $3.4 \mathrm{def}$ & $28.9 \mathrm{abc}$ & $18.8 \mathrm{~d}$ & $23.8 \mathrm{~d}$ & $8.6 \mathrm{abc}$ & $11.0 \mathrm{bcd}$ & $9.8 \mathrm{bc}$ \\
\hline 3 & $5.4 \mathrm{bc}$ & $2.4 \mathrm{c}$ & $3.9 \mathrm{Cd}$ & $24.5 \mathrm{C}$ & $23.3 \mathrm{bcd}$ & $24.0 \mathrm{~d}$ & $9.5 \mathrm{a}$ & $9.4 \mathrm{~d}$ & $9.5 \mathrm{bc}$ \\
\hline 4 & $5.7 \mathrm{ab}$ & $3.7 \mathrm{~b}$ & $4.7 \mathrm{~b}$ & $27.9 \mathrm{abc}$ & $24.3 \mathrm{bcd}$ & $26.1 \mathrm{bcd}$ & $8.2 \mathrm{abc}$ & $13.8 \mathrm{abc}$ & $11.0 \mathrm{ab}$ \\
\hline 5 & 4.3 ef & $3.1 \mathrm{bc}$ & 3.7 cde & $26.5 \mathrm{bc}$ & $22.7 \mathrm{bcd}$ & $24.6 \mathrm{~d}$ & $8.1 \mathrm{abc}$ & $14.0 \mathrm{ab}$ & $11.0 \mathrm{ab}$ \\
\hline 6 & $3.6 \mathrm{gh}$ & $2.6 \mathrm{c}$ & $3.1 \mathrm{f}$ & $29.8 \mathrm{ab}$ & $24.7 \mathrm{bcd}$ & $27.2 \mathrm{bcd}$ & $8.3 \mathrm{abc}$ & $10.4 \mathrm{bcd}$ & $9.3 \mathrm{bc}$ \\
\hline 7 & $4.9 \mathrm{~cd}$ & $2.8 \mathrm{bc}$ & $3.9 \mathrm{~cd}$ & $30.1 \mathrm{ab}$ & $25.7 \mathrm{bc}$ & $27.9 \mathrm{abcd}$ & $8.0 \mathrm{abc}$ & $12.2 \mathrm{abcd}$ & $10.1 \mathrm{bc}$ \\
\hline 8 & $5.2 \mathrm{~cd}$ & $3.1 \mathrm{bc}$ & $4.1 \mathrm{c}$ & $28.6 \mathrm{abc}$ & $24.9 \mathrm{bcd}$ & $26.8 \mathrm{bcd}$ & $8.2 \mathrm{abc}$ & $10.7 \mathrm{bcd}$ & $9.4 \mathrm{bc}$ \\
\hline 9 & $4.9 \mathrm{~cd}$ & $3.0 \mathrm{bc}$ & $4.0 \mathrm{C}$ & $30.8 \mathrm{ab}$ & $20.4 \mathrm{~cd}$ & $25.6 \mathrm{~cd}$ & $8.1 \mathrm{abc}$ & $10.1 \mathrm{Cd}$ & $9.1 \mathrm{bc}$ \\
\hline 10 & $3.4 \mathrm{hi}$ & $3.0 \mathrm{bc}$ & 3.2 ef & $33.0 \mathrm{a}$ & $27.3 \mathrm{~b}$ & $30.1 \mathrm{ab}$ & $8.8 \mathrm{abc}$ & $16.1 \mathrm{a}$ & $12.4 \mathrm{a}$ \\
\hline 11 & $4.7 \mathrm{de}$ & $3.6 \mathrm{~b}$ & $4.1 \mathrm{c}$ & $32.4 \mathrm{a}$ & $27.0 \mathrm{bc}$ & $29.7 \mathrm{abc}$ & $9.5 \mathrm{ab}$ & $10.3 \mathrm{bcd}$ & $9.9 \mathrm{bc}$ \\
\hline 12 & $4.8 \mathrm{de}$ & $3.5 \mathrm{~b}$ & $4.2 \mathrm{c}$ & $31.0 \mathrm{ab}$ & $25.0 \mathrm{bcd}$ & $28.0 \mathrm{abcd}$ & $8.4 \mathrm{abc}$ & $13.4 \mathrm{abc}$ & $10.9 \mathrm{ab}$ \\
\hline 13 & $6.0 \mathrm{a}$ & $4.8 \mathrm{a}$ & $5.4 \mathrm{a}$ & $26.7 \mathrm{bc}$ & $21.4 \mathrm{bcd}$ & $24.1 \mathrm{~d}$ & $7.9 \mathrm{bc}$ & $13.6 \mathrm{abc}$ & $10.7 \mathrm{ab}$ \\
\hline 14 & $4.0 \mathrm{fg}$ & $2.5 \mathrm{c}$ & 3.2 ef & $30.5 \mathrm{ab}$ & $25.0 \mathrm{bcd}$ & $27.8 \mathrm{abcd}$ & $8.1 \mathrm{abc}$ & $10.5 \mathrm{bcd}$ & $9.3 \mathrm{bc}$ \\
\hline 15 & $4.1 \mathrm{fg}$ & $2.4 \mathrm{c}$ & 3.3 ef & $27.2 \mathrm{bc}$ & $36.1 \mathrm{a}$ & $31.7 \mathrm{a}$ & $7.4 \mathrm{c}$ & $9.4 \mathrm{~d}$ & $8.4 \mathrm{c}$ \\
\hline 16 & $3.7 \mathrm{gh}$ & $2.9 \mathrm{bc}$ & 3.3 ef & $29.3 \mathrm{abc}$ & $22.1 \mathrm{bcd}$ & $25.7 \mathrm{Cd}$ & $7.8 \mathrm{c}$ & $13.2 \mathrm{abcd}$ & $10.5 \mathrm{ab}$ \\
\hline Average & 4.5 & 3.1 & 3.8 & 29.4 & 24.5 & 26.9 & 8.3 & 11.8 & 10.05 \\
\hline LSD 0.05 & 0.5 & 0.95 & 0.54 & 5.04 & 6.9 & 4.2 & 1.6 & 3.9 & 2.1 \\
\hline CV\% & 7.4 & 18.3 & 12.3 & 10.3 & 17.0 & 13.5 & 11.8 & 19.9 & 17.9 \\
\hline
\end{tabular}

Means followed by the same letter within each column are not significantly different at 0.05 level of probability, according to LSD 0.05 . 